\title{
Post-Power Syndrome dan Perubahan Perilaku Sosial Pensiunan Guru
}

\author{
Abdul Rahmat, Suyanto \\ Universitas Negeri Gorontalo, Jl. Jenderal Sudirman No.6 \\ e-mail: abdulrahmat@ung.ac.id
}

\begin{abstract}
This study intended to determine the symptoms and the factors of post-power syndrome, as well as some efforts of the teachers in deal with retirement. The qualitative method was used in this study and data was collected through observation, interview and some documentations studied. Sources of data were two retired teachers in MAN 2 Yogyakarta. The result shown some symptoms experienced by the subjects comprised to get closer in worship activities, but emotionally be more temperamental. The most prominent factors of post-power syndrome among the two informants included the loss of social contact with their co-workers, in addition to losing positions, loss of dignity and a sense of meaning, as well as the loss of income sources. Due to retirement, their activities and routines seemed disconnected from other teacher's activities so both of them felt losing social contact with colleagues. Some efforts for minimizing the symptoms of post-power syndrome was involving in forum gathering that held by the school.
\end{abstract}

Keywords: post-power syndrome, teacher, retirement, social contacts

\begin{abstract}
Abstrak
Penelitian ini bertujuan untuk mengetahui gejala-gejala, faktor-faktor post-power syndrome, serta upaya guru pensiun dalam menghadapi post-power syndrome. Penelitian ini menggunakan metode kualitatif dengan teknik pengumpulan data melalui observasi, wawancara dan dokumentasi terhadap obyek yang diteliti. Sumber data adalah dua orang pensiunan guru di MAN 2 Yogyakarta. Hasil penelitian yang dilakukan menunjukan ada beberapa gejala yang dialami oleh subyek, antara lain lebih mendekatkan diri mereka pada kegiatan ibadah namun secara emosi menjadi lebih temperamental. Faktor-faktor post-power syndrome yang paling menonjol pada dua informan dalam penelitian ini adalah kehilangan kontak sosial dengan rekan kerja mereka, selain kehilangan jabatan, kehilangan kewibawaan dan perasaan berarti, serta kehilangan sebagian sumber penghasilan. Setelah mereka pensiun aktivitas dan rutinitas mereka seakan terputus dari guru yang lainnya terlihat dari kehilangan kontak sosial dengan rekan kerja. Sedangkan upaya informan dalam meminimalisir gejala post-power syndrome adalah adanya forum silaturahmi yang diadakan di sekolah.
\end{abstract}

Kata Kunci: post-power syndrome, pensiunan guru, kontak sosial

\section{Pendahuluan}

Bagi hampir semua orang yang normal dan sehat, bekerja menyajikan kehidupan sosial yang mengasyikkan dan persahabatan, yaitu dua hal yang menjadi sumber pokok bagi perolehan kebahagiaan, kesejahteraan, status sosial dan jaminan sosial (Jacinta F.R. 2013:11). Oleh karena itu jawatan atau tempat bekerja adalah sentra sosial yang memberikan makna tersendiri bagi kehidupan individu. Disamping menjamin kesehatan mental, lembaga atau jawatan tempat bekerja memberikan ganjaran materil berupa uang, fasilitas, gaji dan materi lain, maupun ganjaran non materil berupa penghargaan, status sosial dan prestise yang sangat berarti bagi harkat diri individu.

Pegawai Negeri Sipil (PNS) dalam hal ini adalah guru di MAN 2 Yogyakarta juga mendapat hal semacam itu. Namun berbagai hal yang didapat selama bekerja tersebut pada akhirnya akan hilang atau berkurang setelah pensiun datang. Sesuai dengan UU tentang Guru dan Dosen pasal 1 ayat 1 No. 14 tahun 2005 peraturan pemerintah bahwa PNS akan mengalami masa pensiun saat berumur 50-58 tahun, 
dimana mereka telah menjalani masa kerja antara 30 sampai 40 tahun, dengan masa kerja yang begitu lama maka telah terjalin berbagai hubungan baik interpersonal maupun intrapersonal seperti: kecintaan individu pada pekerjaan, aktifitas kerja, hubungan dengan murid-murid, lingkungan kerja dan masyarakat. Hal tersebut akan membuat individu sedih, melankolis, dan perasaan negatif lainnya jika berbagai hubungan yang terjalin selama ia bekerja harus ditinggalkan karena datangnya pensiun (dalam M.W Nasrun, 2013:13)

Berbagai fasilitas dalam bentuk materi seperti: gaji pokok yang berkurang $25 \%$ setelah pensiun, tunjangan fungsional dan kesejahteraan personal akan hilang setelah pensiun. Hal itu membuat banyak orang menghadapi masa pensiun dengan perasaan negatif atau tidak senang. Bahkan mereka yang belum siap mentalnya akan mengalami shock (kejutan) mental yang hebat, sebab kejadian tersebut dianggap sebagai kerugian, keaiban, degradasi sosial, sebagai hal yang memalukan dan sebagainya. Timbulnya perasaan-perasaan negatif tersebut menyebabkan pegawai yang akan menghadapi masa pensiun cenderung dihinggapi perasaan cemas, takut dan khawatir dengan berbagai dampak psikologis dan manifestasi yang menyertainya (Idris, 2004:87).

Individu yang mengalami kecemasan akan terus-menerus mengkhawatirkan segala macam masalah yang mungkin terjadi dan sulit berkonsentrasi untuk mengambil keputusan. Ditambahkan oleh Rumke dalam Hurlock (1996:122) ecemasan sering muncul pada saat individu akan menghadapi masa pensiun, hal ini disebabkan dalam menghadapi pensiun, dalam diri individu terjadi goncangan perasaan yang begitu hebat karena individu harus meninggalkan pekerjaannya, temantemannya dan segala aktivitas lain yang mereka peroleh selama masih bekerja (Hurlock, 1996:125). Perubahanperubahan yang terjadi pada masa pensiun akan menimbulkan goncangan mental yang tidak dapat dielakkan. Hal ini disebabkan karena adanya perasaan tidak rela untuk melepas jabatan yang selama ini telah dimiliki dan dinikmati, jadi pasti ada perasaan cemas dan khawatir, hal ini apabila berlebihan dapat mengganggu keadaan fisik dan psikologisnya. Individu yang mengalami masa pensiun akan mengalami kecemasan dan goncangan perasaan yang begitu berat. Kecemasan ini terjadi karena mereka harus meninggalkan teman-teman baik sebagai atasan ataupun bawahannya. Status sosial ekonomi serta fasilitas-fasilitas lain yang mereka peroleh selama bekerja. Kekhawatiran, kecemasan dan ketakutan yang berkelanjutan akan berdampak pada keseimbangan emosional individu dan akhirnya akan termanifestasi dalam berbagai keluhan fisik, keadaan seperti itu dikenal dengan sebutan postpower syndrome (Haditono, 2012:90).

Masalah kesehatan jiwa akan muncul bila usia tua tidak dapat menyesuaikan diri dengan baik terhadap perubahanperubahan yang terjadi seiring dengan proses penuaan, salah satunya timbul dalam bentuk depresi. Kemampuan usia tua dalam beradaptasi tersebut dipengaruhi oleh tipe kepribadian yang mereka miliki. Tipe kepribadian akan menentukan kerentanan usia tua terhadap terjadinya depresi (Puspasari, 2013:09). Menjalani masa tua dengan bahagia dan sejahtera, merupakan dambaan semua orang. Keadaan seperti ini hanya dapat dicapai oleh seseorang apabila orang tersebut merasa sehat secara fisik, mental dan sosial, merasa dibutuhkan, merasa dicintai, mempunyai harga diri serta dapat berpartisipasi dalam kehidupan. Post-power syndrome banyak dialami oleh mereka yang baru saja menjalani masa pensiun. Istilah tersebut muncul untuk mereka yang mengalami gangguan psikologis saat memasuki waktu pensiun. Stress, depresi, tidak bahagia merasa kehilangan harga diri dan kehormatan adalah beberapa hal yang dialami oleh mereka yang terkena post-power syndrome (Santoso dan Lestari, 2008:99). 
Uraian di atas dapat diinterpretasi bahwa bagi seseorang yang memasuki masa pensiun akan membutuhkan waktu untuk merubah orientasi kehidupannya dari suasana bekerja ke suasana waktu luang yang panjang. Masa pensiun, khususnya di Indonesia merupakan masa yang akan menimbulkan gejolak psikologis mengingat ketika seseorang berusia 55 tahun ia harus memasuki masa pensiun. Hal ini menyebabkan timbulnya gejolak psikologi, yaitu suatu perasaan yang ditandai dengan emosi yang tidak stabil, mudah tersinggung dan marah, serta sering berada dalam keadaan gelisah dan cemas (Avin Fadhilla, 2000: 42-55).

Maka dari itu untuk melihat lebih jauh tentang syndrome yang dialami para pensiunan khususnya guru, perlu pengkajian lebih jauh dengan melakukan penelitian yang mendalam. Dalam hal ini peneliti merasa terpanggil untuk melihat seberapa jauh post-power syndrome yang dialami oleh para pensiunan guru di MAN 2 Yogyakarta. Adapun alasan memilih MAN 2 Yogyakarta dijadikan sebagai obyek dari penelitian ini, karena peneliti melihat bahwa bekerja di MAN termasuk bagian dari status sosial, bahwa menjadi seorang guru bisa diindikasikan gengsi jabatan ataupun peranan guru di masyarakat cukup menyita perhatian serius untuk dikaji lebih dalam.(Wawancara dengan RK, 5 September. 2013). Dengan asumsi inilah peneliti merasa terpanggil untuk terlibat jauh dan untuk mengetahui persoalan-persoalan apa saja yang akan menjadi kajian mendalam dalam hal postpower syndrome bagi pensiunan guru di MAN 2 Yogyakarta tersebut.

Berdasarkan pemikiran di atas, maka peneliti mengajukan tiga rumusan masalah yang akan dijadikan dalam penelitian ini yakni 1) Gejala post-power syndrome apa saja yang dialami oleh pensiunan guru di MAN 2 Yogyakarta ? 2) Faktor apa yang memengaruhi post-power syndrome pada pensiunan guru di MAN 2 Yogyakarta? 3) Upaya pensiunan guru dalam me- nanggulangi post-power syndrome tersebut ?. Dengan masalah tersebut, maka tiga tujuan dari penelitian ini. Pertama, untuk mengetahui gejala-gejala post-power syndrome pada pensiunan guru di MAN 2 Yogyakarta. Kedua, untuk mengetahui faktor yang mempengaruhi post-power syndrome pada pensiunan guru di MAN 2 Yogyakarta. Ketiga, untuk mengetahui upaya pensiunan guru dalam menanggulangi post-power syndrome.

Penelitian ini merupakan field reseacrh (penelitian lapangan) dengan pendekatan kualitatif sehingga hasil yang diteliti bersifat deskripsi-analitis (Moleong, 2010). Pada awalnya, data-data mengenai post-power syndrome bagi pensiunan guru di MAN 2 Yogyakarta dikumpulkan dengan metode pengamatan secara langsung, wawancara mendalam dan studi dokumentasi. Metode pengamatan terlibat digunakan untuk mengamati tentang kondisi, aktivitas dari pensiunan guru, dimana peneliti turut melibatkan diri dari bagian keseharian individu yang diteliti dalam penelitian ini. Metode wawancara dilakukan secara dialogis dengan kedua subyek penelitian yang merupakan pensiunan guru di MAN 2 Yogyakarta. Sementara itu, studi dokumentasi diharapkan untuk menguji dan menafsirkan datadata dari pengamatan dan wawancara mendalam.

\section{Tinjauan Teori: Post-Power Syndrome \\ Pengertian post-power syndrome.}

Post-Power Syndrome dialami terutama orang yang sudah lanjut usia dan pensiun dari pekerjaannya. Hanya saja banyak orang yang berhasil melalui fase ini dengan cepat dan dapat menerima kenyataan dengan hati yang lapang. Tetapi pada kasus-kasus tertentu, dimana seseorang tidak mampu menerima kenyataan yang ada, ditambah dengan tuntunan hidup yang terus mendesak, dan dirinya adalah satu-satunya penopang hidup keluarga, resiko terjadinya Post- 
Power Syndrome semakin besar (Elia, 2003).

Menurut Elia (2003:5) yang dimaksud dengan Post-Power Syndrome adalah kumpulan gejala. Power adalah kekuasaan. Jadi, terjemahan dari PostPower Syndrome adalah gejala pasca kekuasaan. Gejala ini umumnya terjadi pada orang-orang yang tadinya mempunyai kekuasaan atau menjabat satu jabatan, namun ketika sudah tidak menjabat lagi, seketika itu terlihat gejalagejala kejiwaan atau emosi yang kurang stabil. Gejala itu biasanya bersifat negatif, itulah yang diartikan Post-Power Syndrome.

Prawitasari (2012:14) menambahkan Post-Power Syndrome biasanya dialami oleh pejabat-pejabat pemerintah yang memiliki kekuasaan yang tinggi yang biasa disanjung oleh anak buah atau orang lain yang mempunyai kepentingan dengannya.

Masa pensiun ini dapat menim-bulkan masalah karena tidak semua orang siap untuk menghadapinya. Pensiun akan memutuskan seseorang dari aktivitas rutin yang telah dilakukan selama bertahuntahun, selain itu akan me-mutuskan rantai sosial yang sudah terbina dengan rekan kerja, dan yang paling vital adalah menghilangnya identitas diri seseorang yang sudah melekat begitu lama (Agustina, 2008:89).

Maka dari itu, Post-Power Syndrome memiliki ciri yang melekat pada diri yang mengalaminya, se-bagaimana yang diungkapkan oleh Elia bahwa ciri-ciri tersebut adalah;

Orang yang senang dihargai dan dihormati orang lain, yang permintaannya selalu dituruti, yang suka dilayani orang lain.

Orang-orang yang membutuhkan pengakuan dari orang lain karena kurangnya harga diri, sehingga jika individu tersebut memiliki jabatan dia merasa diakui oleh orang lain.
Orang-orang yang menaruh arti hidupnya pada prestasi jabatan dan pada kemampuan untuk mengatur hidup orang lain, untuk berkuasa terhadap orang lain. Istilah orang yang menganggap kekuasaan itu segala-galanya.

Post-Power Syndrome adalah gejala ketidakstabilan psikis seseorang yang muncul pada dirinya setelah hilangnya jabatan atau kekuasaan. Gangguan ini terjadi pada orang yang merasa dirinya sudah tidak dianggap dan tidak dihormati lagi.

\section{Gejala-gejala post power syndrome}

Gejala-gejala Post-Power Syndrome menurut Elia akan dirasakan individu dengan meiliputi beberapa gejala, diantaranya;

Gejala fisik, misal bagi orang-orang yang menderita Post-Power Syndrome biasanya tampak menjadi jauh lebih cepat tua dibandingkan pada waktu dia masih menjabat. Tanpa diduga tiba-tiba rambutnya menjadi putih, berkeriput, menjadi pemurung dan mungkin sakitsakitan.

Gejala emosi, miaslnya cepat mudah tersinggung, merasa tidak berharga, ingin menarik diri dari lingkungan pergaulan, ingin bersembunyi dan lain-lain.

Gejala perilaku, missal malu bertemu dengan orang lain, lebih mudah melakukan pola-pola kekerasan atau menunjukan kemarahan baik di rumah atau tempat lain (Elia, 2003:99).

Menurut Supeno individu yang mengalami Post-Power Syndrome menunjukkan adanya gangguan baik sikap maupun perilaku. Gaya sikap atau perilaku merupakan manifestasi dari reaksi-reaksi kejiwaan yang terjadi pada diri individu tersebut (Supeno, 1992:62). Gangguan sikap dan perilaku tersebut adalah reaksi eksplosif, seperti kehilangan kendali, emosi meledak-ledak, marahmarah, serta agresi verbal dan fisik, memperlihatkan gejala frustasi yang ditandai dengan timbulnya kecemasan dan 
depresi, reaksi mekanisme pertahanan diri, seperti reaksi substitusi, dan selalu mengenang hal-hal yang menyenangkan di masa lalu sehingga timbul sikap-sikap yang kadang tidak diterima oleh keluarga.

Berdasarkan pada uraian di atas maka dapat disimpulkan dari gejal-gejala orang yang mengalami Post-Power Syndrome adalah gejala fisik, emosi dan perilaku.

Faktor yang mempengaruhi postpower syndrome. Banyak faktor yang memengaruhi seseorang menderita gejala Post-Power Syndrome, dalam hal ini paling tidak yang khusus tentang pensiunan guru ada beberapa faktor diantaranya adalah;

Kepuasan kerja dan pekerjaan. Ketika seseorang sudah memasuki masa pensiuan secara otomatis kepuasan dalam diri mereka untuk bekerja menjadi salah satu faktor mengalami Post-Power Syndrome.

Usia. Usia memang menjadi faktor penentu dalam mengalami gejala PostPower Syndrome. Karena ketika usia semakin lanjut, maka pola pikir dan perilaku pun akan semakin menurun.

Kesehatan. Jelas sekali kesehatan akan memengaruhi gejala Post-Power Syndrome pada diri seseorang. Semakin tua seseorang, maka gejala kesehatan yang menurun pun akan terlihat.

Status sosial sebelum pensiun. Biasanya orang yang menderita gejala Post-Power Syndrome mengalami depresi yang cukup akut, karena dalam status sosial mereka akan terpengaruhi, sebagaimana menjadi orang biasa lagi (Rini, 2001:90).

Berdasarkan pada faktor-faktor tersebut, maka dapat diambil kesimpulan bahwa yang memengaruhi Post-Power Syndrome itu adalah faktor kepuasan kerja dan pekerjaan, usia, kesehatan, dan status sosial di masyarakat sebelum pensiun.

Pengertian pensiunan guru. Menurut Poerwadarminta guru adalah orang yang kerjanya mengajar (Poerwadarminta, 1983:335). Sedangkan menurut Djamarah (2005:21) guru adalah semua orang yang bertanggungjawab dan yang berwenang terhadap pendidikan murid-muridnya baik secara individu ataupun secara klasikal, di sekolah maupun diluar sekolah. Pensiun berarti bahwa perusahaan memberikan sejumlah uang tertentu secara berkala kepada karyawan yang telah berhenti bekerja setelah mereka bekerja dalam waku yang lama, atau setelah mencapai suatu batas usia tertentu.

Flippo menyebut pensiun me-rupakan suatu peran tanpa peran. Dalam suatu masyarakat dibangun berdasarkan etika kerja, peralihan dari suatu peran kerja produktif yang nyata pada suatu hari telah menanamkan keyakinan bahwa pensiun mengakibatkan penyakit mental dan jasmani serta kadang-kadang ke-matian yang terlalu cepat. Pensiun merupakan suatu peritiwa dalam daur kehidupan seseorang, pensiun memaksa suatu peningkatan dalam ruang lingkup pengambilan keputusan tentang kehidupan pribadi seseorang (Flippo, 1987:283).

Schwartz dalam Hurlock (1992) berpendapat bahwa pensiun merupakan akhir pola hidup atau transisi ke pola hidup baru. Pensiun selalu menyangkut perubahan peran, perubahan keinginan dan nilai, serta perubahan secara keseluruhan terhadap pola hidup setiap individu (Hurlock, 1992:417). Jadi dapat ditarik benang merahnya bahwa pensiunan guru adalah seseorang yang mengalami masa transisi menuju ke hidup baru karena kondisi fisik dan batasan usia, setelah sekian lama mengabdikan dirinya kepada bangsa sebagai pengajar.

Kategori sikap terhadap pensiun. Hurlock (1992) membagi sikap pensiun ke dalam dua kategori, yaitu;

Pengalihan peran (Transformer), yaitu mengubah gaya hidup dengan menciptakan gaya hidup baru dan menyenangkan diri sendiri. Melepaskan berbagai peran lama dan menjalankan peran baru. 
Pemeliharaan peran (Maintainers). Terus bekerja dengan melakukan pekerjaan penggal waktu setelah pension. Pekerjaan yang dilakukan merupakan lanjutan dari pekerjaan yang sebelumnya ((Hurlock, 1992:418).

Berdasarkan dengan pembagian kategori tersebut, maka dapat diambil kesimpulan bahwa peran pensiun dapat menjadi pengalihan peran dan pemeliharaan peran. Bagi yang sudah terbiasa dengan gaya hidup peran ganda ketika mereka masih menjabat sebagai guru, dampak terhadap gejala post-power syndrome tidak akan terlalu berdampak buruk.

\section{Metode Penelitian}

Penelitian ini menggunakan metode kualitatif dengan pendekatan penelitian lapangan (field research). Pengumpulan data diambil dengan cara observasi, wawancara dan dokumentasi terhadap obyek yang diteliti. Sumber data adalah pensiunan guru di MAN 2 Yogyakarta. Hasil penelitian menunjukan ada beberapa gejala yang dialami oleh dua subyek. Dalam penelitian kualitatif informasi yang dikumpulkan dan diolah harus tetap obyektif dan tidak dipengaruhi oleh pendapat peneliti sendiri. Penelitian kualitatif banyak diterapkan dalam penelitian historis atau deskriptif. Sumber data utama dalam penelitian adalah informan kunci. Alasan ditetapkannya informan kunci karena yang bersangkutan memiliki otoritas kepemimpinan tertinggi. Di samping itu, dianggap sebagai seseorang yang paling mengerti dan bertanggung jawab terhadap ber-langsungnya pendidikan kursus. Peneliti juga akan mencari informan-informan lain yang dianggap dapat melengkapi informasi yang dibutuhkan. Informan-informan lain tersebut adalah para wakil atau jabatan lain yang selevel yang ditentukan dengan teknik snowball sampling.
Untuk mendapatkan data penelitian ini, menggunakan langkah-langkah pengumpulan data sebagai berikut:

\section{Wawancara}

Dalam penelitian ini yang dilakukan dengan cara tanya jawab langsung dengan semua informan yang dipilih berdasarkan kebutuhan dalam penelitian sebagai sumber data yang utama dalam penelitian ini. Dalam kegiatan wawancara ini, penulis menggunakan panduan sehingga wawancara dapat berjalan sesuai kebutuhan penelitian dan akan dilaksanakan secara berulang-ulang sampai diperoleh data yang meyakinkan apa yang akan diteliti. Hal ini dimaksud agar wawancara dapat beerlangsung dengan lancar dan informan dapat memberi informasi secara akurat, terbuka dan menyeruh tanpa keraguan terhadap peneliti.

\section{Observasi}

Dalam penelitian ini, penulis melakukan pengamatan langsung, sehingga untuk menjaring informasi yang diperlukan dalam penelitian ini dilakukan secara berstruktur yang berarti apa yang dilakukan dan diamati telah disusun sebelumnya oleh peneliti dan mencatat langsung hasil pengamatan sesuai kondisi situasi yang ditemui dilokasi penelitian.

\section{Dokumentasi}

Data yang diperoleh dari dokumen-tasi terdiri atas berbagai tulisan dan rekaman data, seperti profil Meubel Sepakat, catatan harian dan data lain yang berhubungan dengan fokus penelitian.

Untuk menganalisaan data ditempuh melalui langkah-langkah yakni:

\section{Reduksi Data}

Reduksi data bermaksud untuk merangkum dengan menonjolkan hal-hal pokok yang refelen dan fokus penelitian, proses ini dimulai dari menelaah data yang ada. 


\section{Penyajian Data}

Penyajian dalam penelitian ini juga dimaksudkan untuk menemukan suatu makna dari data-data yang telah diperoleh, kemudian disusun secara sistematis, dari bentuk informasi yang kompleks menjadi sederhana namun selektif. Penyajian data akan disajikan dalam bentuk naratif, sesuai dengan focus penelitian.

\section{Penarikan Kesimpulan Atua Verifikasi}

Penarikan kesimpulan dmaksud untuk memadukan semua data yang diperoleh lalu dikumpulkan guna menarik kesimpulan dari berbagai hasil analisis yang baik melalui catatan lapangan, hasil observasi dan dokumen-dokumen.

Pengecekan keabsahan data merupakan konsep penting dalam jenis penelitian kualitatif. Adapun teknik yang digunakan peneliti untuk memperoleh hasil yang maksimal dalam pengecekan keabsahan data yaitu memperpanjang kehadiran peneliti di lokasi penelitian sehingga dapat mengamati dengan teliti seluruh kegiatan dilokasi penelitian.

\section{Hasil dan Pembahasan}

\section{Gejala Post-Power Syndrom}

Post power syndrom pada umumnya akan dialami bagi mereka yang mempunyai jabatan. Hal ini akan dirasakan karena setiap individu sudah merasakan nyaman pada posisi sebelumnya. Di masa sudah tua atau dalam menghadapi pensiunan pasti akan merasakan hal baru dalam hidupnya. Tadinya disegani oleh bawahannya, kini setiap individu yang akan pensiun harus menjadi orang biasa kembali. Akan tetapi, gejala post power syndrom akan dirasakan oleh setiap orang yang berada di bawah lingkungan instansi atau pegawai pemerintahan. Hal ini dikarenakan banyak faktor yang menyebabkan hal demikian.

Secara umum gejala post power syndrom yang dialami oleh pensiunan ada tiga komponen pokok yakni dalam gejala perilaku, gejala emosi dan gejala fisik. Secara sederhana pensiunan akan menghadapi gejala fisik dari akibat stress yang akan dihadapinya. Gejala fisik ini akan dilihat dari beberapa unsur berikut yang nantinya peneliti teliti dilapangan terhadap dua subyek pensiunan guru di MAN 2 Yogyakarta, yakni:

Reaksi eksplosif, seperti kehilangan kendali, emosi meledak-ledak, marahmarah, serta agresi verbal dan fisik.

Memperlihatkan gejala frustasi yang ditandai dengan timbulnya kecemasan dan depresi.

Reaksi mekanisme pertahanan diri, seperti reaksi substitusi.

Selalu mengenang hal-hal yang menyenangkan di masa lalu sehingga timbul sikap-sikap yang kadang tidak diterima oleh keluarga.

Maka dari itu, untuk mengetahui seberapa jauh gejala yang dialami oleh subyek penelitian yang diteliti pada kajian ini, kami mencoba menganalisis dengan melakukan wawancara dan observasi langsung ke lapangan sebagai bagian dari cara pengambilan data dalam penelitian ini. Untuk itu, kami mencantumkan hasil analisis tersebut dari gejala yang dialami subyek penelitian.

\section{Gejala yang dialami subyek penelitian 1}

Untuk mengetahui gejala yang dialami oleh subyek 1, maka peneliti menceritakan kronologis dari hasil observasi di lapangan sebagaimana berikut, setelah bercerita tentang pengalaman yang dialami sewaktu di sekolah, mulai dari waktu mengajar pertama kali hingga diangkat PNS sampai pada masa pensiun, subyek 1 bercerita sambil bercanda dengan penuh tawa sambil mengingat-ingat masa lalu yang dijalaninya. Setelah ngobrol dengan rasa tenang peneliti secara langsung mengamati dengan seksama perilaku subyek 1, mengamati secara emosi maupun secara fisik. Pengamatan secara fisik ketika bertemu untuk melakukan 
wawancara, subyek 1 kelihatan sudah mulai menua. Secara fisik semakin berkurang, dilihat dari kulit yang mulai mengkerut di bagian wajah dan tangan. Karena subyek 1 memakai kerudung, peneliti hanya melihat sebagian saja. Tetapi peneliti melihat rambut beliau semakin memutih, sedikit terlihat di selasela pinggir kerudung. Waktu itu, subyek 1 memakai baju kebaya putih mengenakan kerudung abu-abu. Selain itu, peneliti melihat subyek 1 secara emosi tidak terlalu menggebu-gebu ketika berbicara (Observasi 3 September, 2013). Saat sedang bercerita, subyek 1 terlihat senang dengan kehidupan di masa tua. Ybs masih terbilang stabil secara emosi di usia renta ibu NZ. Hanya saja dari mimik wajah nampak gejala-gejala post-power syndrome. Misalnya dalam penuturan kata-kata yang kurang fasih dalam penyampaian kalimat.

Setelah proses wawancara tersebut selesai, kemudian peneliti mengamati kembali perkembangan emosi yang dialami dan dirasakan sejauh perkembangan yang ada. Hal ini berdasarkan observasi dan analisis peneliti berikut ini; dalam proses pengamatan yang dialami peneliti, kondisi fisik dan secara emosi dari subtek 1 memperlihatkan dalam kondisi yang tidak stabil. Misalnya saat memanggil pembantunya untuk mengambilkan minuman. Selain itu, dalam memberikan jawaban-jawaban yang diungkapkan pada peneliti. Subyek mengakui bahwa tidak mengalami masalah ketika menghadapi pensiunan, tetapi dilihat dari pemaparan yang disampaikannya dan pengamatan secara langsung seakan ada sesuatu yang dirasakan, namun berusaha ia sembunyikan. Seperti halnya ia ingin menjalankan tugasnya sebagai PNS lebih lama lagi. Subyek 1 sudah pensiun sejak tahun 2009, jadi sebetulnya ia sudah cukup lama pensiun sekitar 3 tahun yang lalu. Ketika proses wawancara, subyek 1 dalam menjawab setiap pertanyaan menunjukkan emosi yang kurang terkontrol dengan baik terlihat dari tempo, tekanan serta volume bicaranya (Observasi 3 September, 2013).

Dilihat dari segi perilaku, tidak terlalu kelihatan ada indikasi post power syndrom. Tetapi setelah intens melakukan observasi dan mendengarkan cerita yang disampaikan subyek 1 , terlihat ada gejala perilaku dari post power syndrom. Ketika berbicara terkait aktivitas yang dilakukan. Sebagaimana dulu ketika masih mengajar, kegiatan subyek 1 berangkat pagi dan pulang sore telah menjadi rutinitas yang dilakukan selama puluhan tahun. Tetapi setelah pensiun ia hanya mengikuti kegiatan-kegiatan yang ada dimasyarakat seperti mengikuti pengajian mingguan, aktif di PKK, maupun ikut organisasi pensiunan guru MAN Pacitan. Sebagaimana hasil wawancara berikut ini:

"Nggak saya ga gelisah... saya masih tenang soalnya saya lebih memperbanyak ibadah kepada Allah, memperbanyak sholat sunah, memperbanyak puasa sunah, aktif mengikuti pengajian-pengajian, ya jadi seneng... tidak begitu juga, ketika mau sholat sunat ya saya sempatkan ke masjid untuk sohlat dhuha. Kalau puasa ya saya sempatkan..setiap ba'da shubuh ada pengajian ibu-ibu membahas kaidah yang ada dalam tafsir Al-Misbah. Yang dilakukan madrasah, saya kan pembina bidang keagamaan di madrasah ya 2 tahun sebelum pensiun saya malah dipindah tugaskan ke DEPAG, ya sebenarnya nanggung". (Wawancara 3 September, 2013).

Kebiasaan subyek 1 saat ini tentu berbeda dengan saat ketika ia masih menjadi guru. Kini ia harus kembali menjadi masyarakat biasa, hal ini menunjukan bahwa dalam segi sikap subyek 1 mengalami post power syndrome, tetapi jika perhatikan tidak begitu akut, karena ia mampu mencari jalan lain untuk mengisi waktu yang kosong. Analisis yang dilakukan oleh peneliti terhadap terhadap data dari subyek 1 mengasumsikan bahwa ia masuk dalam kategori penyandang post 
power syndrome. Hal ini dibuktikan dengan adanya tanda-tanda yang menjadi batasan gejala post power syndrom dalam penelitian ini, yakni melihat dari segi emosi, sikap dan perilaku. Dilihat dari sisi emosi memperlihatkan bahwa subyek 1 nampak gugup dalam menyampaikan jawaban-jawaban yang dilontarkan oleh peneliti. Hal ini mungkin dipengaruhi oleh faktor usia yang semakin menua. Sisi fisik terlihat jelas dengan semakin banyaknya uban yang tumbuh dikepala, hal ini membuktikan salah satu gejala post power syndrom.

\section{Gejala yang dialami Subyek penelitian 2}

Post Power Syndrome adalah gejala yang muncul ketika seseorang tidak lagi menduduki suatu posisi sosial, biasanya suatu jabatan dalam institusi tertentu. Misal seorang direktur yang mencapai usia pensiun. Gejala ini bisa pula dirasakan oleh orang-orang yang tadinya memiliki karier yang cemerlang, tapi harus melepaskan kariernya tersebut karena faktor-faktor tertentu.

Biasanya gejala ini akan ditandai dengan munculnya gangguan emosional yang bersifat negatif. Kecemasan, rasa putus asa, ketakutan, kekhawatiran akan masa depan, dan lain sebagainya cenderung tampak pada orang-orang yang mengalami gejala ini. Hal ini tampak lebih jelas ketika wawancara yang dilakukan oleh peneliti dengan subyek 2, dimana hasil wawancaranya sebagai berikut ini:

"Saya waktu di Aliyah sebelum pensiun ada promosi pengawas, maksudnya dialih tugaskan gitu. Pada prinsip dan hati nurani saya sebenarnya saya tidak mau. Sampai datang seorang pengawas untuk menarik saya ikut menjadi pengawas madrasah kabupaten Pacitan, saya merasa tidak mampu apalagi keadaan saya sudah tua, tau sendiri jalan pacitan itu seperti apa saya katakan saya tidak sanggup. Akhirnya saya menghadap kepala sekolah menyampaikan keluhan takutnya saya tidak bisa melaksanakan tugas. Kata kepala sekolah pengawas itu kan ada mobil dinas, jadi untuk kemana-mana mengawasi madrasah bisa menggunakan mobil dinas yang disediakan. Jadi sudah ada sopirnya tinggal jalan. Menurut beliau saya itu kan sudah lama di madrasah jadi dinilai dari segi pengalaman, manajemen itu mampu.. saya dilantik saja pada waktu itu tidak datang karena ada rapat persiapan BP3 dengan wali murid. Kalau saya mau memilih saya memilih untuk sampai dengan pensiun tetap di MAN, ya ibarat sudah melekat hati saya dengan madrasah. Ya sudah seperti rumah sendiri. Mudah-mudahan MAN bisa memiliki pendidik yang berkarakter Islami sehingga menciptakan generasi yang unggul di mata Allah SWT. Cucuran air mata yang mengalir karena kami dianggap orang tua disitu, guru-guru juga merasa kehilangan sekali namun sebagai manusia saya memberikan semangat dan tidak larut dan kondisi seperti ini, saya berpesan inilah generasi yang harus kita didik dan kita bina untuk menjadi anak yang berguna. Ya yang baik kita pegang dan yang tidak baik kita perbaiki" (Wawancara 5 September, 2013).

Mencermati hasil wawancara tersebut, gejala post power syndrome yang dirasakan oleh subyek 2 terlihat jelas ketika prosesi pelepasan ybs dari seorang guru menjadi pengawas dengan istilah BP3. Tentu jika dilihat dari analisis perilaku menjelaskan bahwa post power syndrome telah menjadi persoalan yang muncul pada subyek 2. Selain dari segi perilaku, peneliti melihat dari segi emosi terlihat labil dan dari fisik semakin tua. Ketika bertemu untuk wawancara, subyek 2 terlihat terus memperhatikan peneliti. Ybs lupa-lupa ingat dengan saya sewaktu di MAN Pacitan. Tak panjang lebar yang dibahas dalam wawancara kali ini, peneliti mengobservasi subyek 2 baik secara fisik, emosi maupun perilaku selama wawancara berlangsung. Wawancara lebih menggali seputar pengalaman hidup subyek 2 dan di akhir masa-masa pensiun 
dari sekolah (Observasi 5 september, 2003).

Bila dianalisis terhadap subyek 2 ini, secara teoritik dan aplikasi terhadap objek yang dianalisis maka peneliti bisa menyimpulkan bahwa subyek 2 memiliki gejala post power syndrome. Hal ini bisa dilihat dari segi fisik yang terlihat semakin tua juga mengalami gejala kolestrol dan gula darah. Begitu pula secara emosi, terkadang subyek 2 kurang mampu mengontrol emosi. Inilah salah satu yang menyebabkan subyek 2 terkena post power syndrome yang bisa peneliti sebut pada ring satu. Setelah pensiun dari guru, ybs tidak berdiam diri. Tetapi melakukan aktivitas lain seperti rutin mengikuti pengajian mingguan, aktif di PKK dan lain-lain.

\section{Faktor-Faktor Post Power Syndrom}

Setelah melakukan pencarian dan pendalaman data kepada subyek 1 dan subyek 2, dapat memperjelas dan mempermudah pemahaman pada gejala yang dialami oleh kedua subyek tersebut. Untuk itu, beberapa faktor yang memengaruhi hal ini adalah sebagaimana dijelaskan dalam sub bab berikut ini.

Usia yang bertambah tua. Beberapa kasus terkait usia yang bertambah tua dan berakhirnya masa jabatan dirasakan oleh subyek 1, ber-dasarkan hasil observasi dan wawancara berikut ini:

"Waktu itu saya sampai sakit lho, nangis ya gimana saya sudah mengabdi selama 25 tahun di madrasah. Waktu itu madrasah belum punya tanah dan gedung. Bapak ibu guru itu iuran untuk membeli tanah itu, ya yang sekarang untuk asrama, duuuh tinggal dua tahun lagi pensiun masya Alloh, ya ko malah dipindah, sewaktu saya masih jadi pembina keagamaan saya mengontrol anak-anak gimana sholatnya, wudhunya udah bener apa belum, saya menangis menghadap kepala Depag, ko saya harus dipindahkan, ibarat pohon itu kita nanam dari bibitnya, tapi ya alhamdulillah masih tetap ada silaturahmi kepada madrasah"(Wawancara 3 September, 2013).

Peralihan tugas yang dialami oleh subyek 1 membuat dirinya terpukul, karena dengan dipindahtugaskan ia merasa kehilangan anak-anak yang dicintainya - dalam arti anak didik - ia merasa kewajiban menjadi seorang guru terampas haknya untuk bisa memerhatikan lebih intens kepada para siswa seperti perhatian siapa yang akan membimbing mereka sholat, belajar dengan rajin dan lain-lain. Karena menjadi penyuluh agama terasa membebaninya untuk interaksi dengan murid terkekang oleh ruang dan waktu. Walaupun secara esensial sama saja, mungkin aktivitas yang lebih dekat tidak begitu bisa memerhatikan dengan jelas.

Begitu pula yang dialami oleh subyek 2 , ia mengalami goncangan batin ketika dipindah tugaskan dari Aliyah ke Depag dengan status penyuluh agama. Sebagaimana hasil wawancara berikut ini:

"Cucuran air mata yang mengalir karena kami dianggap orang tua disitu, guru-guru juga merasa kehilangan sekali namun sebagai manusia saya memberikan semangat dan tidak larut dan kondisi seperti ini, saya berpesan inilah generasi yang harus kita didik dan kita bina untuk menjadi anak yang berguna. Ya yang baik kita pegang dan yang tidak baik kita perbaiki”(Wawancara 5 September. 2013).

Pengalaman yang dirasakan oleh subyek 2 sampai pada tingkat bimbang berlanjut pada kesedihan saat harus dipindahtugaskan. Awalnya ia berstatus guru Aliyah, kini harus menjadi penyuluh agama dilingkungan Kementerian Agama Wilayah Kabupaten Pacitan yang bertugas untuk mengawasi perkembangan di setiap sekolah dan madrasah di Kabupaten Pacitan.

Peneliti mengamati terhadap perilaku dan kondisi fisik dari kedua subyek penelitian. Secara fisik kedua subyek dari sisi usia semakin tua, terlihat uban semakin banyak tumbuh. Perubahan kulit semakin terlihat keriput sejalan dengan 
usia yang semakin lanjut. Secara teori tidak ada yang bisa terlepas dari faktor usia yang akan membawa seseorang menjadi lupa atau pikun bahkan bisa saja menjadi faktor utama dalam hal munculnya gejala post power syndrome. Gejala ini tidak hanya dirasakan oleh individu yang mempunyai jabatan, tetapi semua pihak yang ada pastinya akan terpengaruhi oleh hal tersebut. Seseorang yang masih muda belum tentu bisa tua, tetapi yang tua pasti pernah mengalami masa muda.

\section{Kepuasan Kerja dalam Pekerjaan}

Berdasarkan pada data yang di dapat dilapangan faktor selanjutnya terkait post power syndrome bagi pensiunan guru adalah kepuasan kerja dalam pekerjaan. Ini artinya, yang biasanya setiap hari pergi ke kantor selain untuk mengajar para guru pun biasanya memanfaatkan waktu luang dengan bersosialisasi sesama temen guru lainnya. Ketika pensiun hal ini akan berkurang karena sudah tidak ada lagi beban tugas yang diembannya sebagai PNS. Hal ini senada dengan hasil observasi berikut ini dengan studi kasus yang diolah oleh peneliti. Terdapat dua subyek yang menjadi pokok bahasan dalam penelitian ini. Hasil dari kedua subyek memperlihatkan perbedaan pada persoalan yang dihadapi tentang pertemanan sewaktu di sekolah mengajar.

Pada kasus subyek 1, diperoleh data mengenai faktor penyebab post power syndrome yaitu kehilangan kontak sosial pada rekan kerja, subyek mengatakan tidak pernah berhubungan dengan temantemannya. Komunikasi subyek dengan teman-teman di kantor juga sudah tidak berjalan lagi. Pensiun tentunya menyebabkan individu kehilangan sebagian besar kelompok sosialnya. Individu yang sebagian besar waktunya digunakan di lingkungan pekerjaan maka kelompok sosial yang paling besar dimilikinya adalah teman-teman sejawat, bawahan, atasan, maupun klien-kliennya. Akibat- nya, pada saat pensiun, mereka merasa kehilangan harga diri dan kesepian, karena tidak memiliki teman-teman. Untuk mengatasi kehilangan kontak sosial yang dirasakannya, maka individu harus mencari aktivitas-aktivitas dan orangorang di lingkungan yang baru sebagai sumber dukungan sosial baginya.

Sedangkan pada subyek 2 kehilang-an kontak sosial bukan merupakan faktor penyebab terjadinya gejala post power syndrome, karena hubungan komunikasi subjek masih berjalan melalui telepon maupun SMS dan mengikuti ibu-ibu PKK.

Berdasarkan kasus diatas dapat dilihat perbedaan yang cukup signifikan antara keduanya. Hal ini disebabkan subyek 1 secara usia sudah lanjut sedang-kan untuk subyek 2 usianya kurang lebih berbeda 5 tahun. Jadi diantara dua subyek yang diteliti pada kasus ini keduanya samasama kehilangan kelompok sosial yang biasanya menjadi bagian hidup walaupun satu subyek masih sering melakukan komunikasi via telpon, sms maupun aktivitas organisasi PKK. Sesuai dengan hasil wawancara berikut ini:

"Sebetulnya saya ini mas kesepian karena sejak saya pensiun di tahun 2009 yang lalu. Tapi saya coba untuk mengganti aktivitas lain untuk menghilangkan kesepian tersebut. Ya mungkin saya memperbanyak ibadah kepada Allah, ikut pengajian sama ibu-ibu dikampung dan lebih mendekatkan dirilah pada Tuhan. Ya mas, ibu juga tahu hal ini membuat jalinan komunikasi dengan teman-teman selama dikantor terputus tetapi tidak dijadikan sebuah alasan bagi saya untuk tidak bangkit donk. Harus tetap melakukan aktivitas-aktivitas yang bermanfaat bagi masyarakat" (Wawancara 5 September 2013).

Semua itu tidak terlepas dari kepuasan kerja yang dialami oleh kedua informan di atas. Karena semua pastinya akan mengalami hal-hal sulit dalam bekerja. Biasanya kesalahan waktu bekerja karena belum sempat memper- 
baikinya karena sudah saatnya pensiun, orang cenderung merasakan tidak puas dalam bekerja. Begitu pula yang dirasakan oleh kedua subyek dalam kepuasan kerja jelas terlihat ketika adanya penjelasan merasa sedih ketika masa pensiun tiba.

\section{Status Sosial Sebelum Pensiun}

Salah satu yang menjadi beban dan menjadi salah satu faktor terjadinya krisis post power syndrome pada individu adalah status sosial sebelum pensiun. Apabila subyek pernah menjabat jabatan struktural di instansi pemerintah tentu hal ini akan menyebabkan kenyataan lain dan berbeda. Untuk melihat lebih jelas tentang kehilangan wibawa bagi subyek peneliti menyajikan hasil observasi dan mengamati proses interaksi subyek 1 dan 2 yang memiliki karakteristik yang berbeda.

Kedua subyek mengatakan setelah pensiun mereka merasakan kehilangan pekerjaan yang dahulu dikerjakannya. Selain itu, pada subyek 2 mengatakan pada usianya saat itu dirinya tidak mampu melakukan suatu pekerjaan baru. Sedangkan subyek 1 masih ada keinginan untuk tetap bekerja akan tetapi keadan fisik subyek sudah tidak mendukung karena sesuai dengan UU tentang Guru dan Dosen pasal 1 ayat 1 bahwa usianya sudah memasuki usia pensiun. Kedua subyek juga mengatakan setelah pensiun ini, subyek jarang berkunjung ke kantor atau bahkan tidak pernah. Bahkan subyek 1 mengatakan bahwa ia merasa menjadi orang asing apabila datang ke tempat bekerjaya dulu, sedangkan pada kasus subyek 2 mengatakan bahwa rekan seangkatannya sudah tidak bekerja lagi di madrasah tersebut, sehingga ia tidak pernah datang ke madrasah.

Jika dianalisis dari hasil observasi tersebut, masa pensiun merupakan masa kesenangan karena bebas dari kewajiban untuk bekerja, akan tetapi masa pensiun juga harus menghadapi kehilangan teman sejawat, merasa diri tidak dihargai dan ditolak apabila ia menghadapi masa pensiun dengan sikap masa bodoh dengan menganggap biasa saja dan mereka tidak mempersiapkan dengan hati-hati. Maka hal tersebut akan dirasakan oleh sebagian pensiunan. Selain itu, jabatan memberikan perasan berarti yang menunjang peningkatan kepercayaan diri seseorang. Misalnya saja, kehilangan kewibawaan di depan anak buah atau lingkungan sekitar karena sudah tidak menjabat lagi. Pekerjaan yang dilakukan individu sebelum pensiun mungkin merupakan pekerjaan yang dapat menimbulkan kepuasan dan keberartian diri bagi individu. Memasuki masa pensiun, berarti segala atribut yang dimilikinya harus ditanggalkan termasuk pekerjaan yang menimbulkan kepuasan tersebut, maka individu perlu menyiapkan kegiatan pengganti agar kehilangan tersebut tidak menjadi masalah.

\section{Kesehatan dan Sumber Penghasilan}

Kehilangan sebagian sumber penghasilan merupakan dampak yang nyata dirasakan oleh kedua subyek. Pada kasus subyek 1 mengenai faktor-faktor penyebab post power syndrome yaitu kehilangan sebagian sumber penghasilan. Setelah pensiun, subyek 1 merasakan berkurangnya penghasilan selain itu terjadi perubahan pola hidup keluarga. Terjadinya perubahan pola hidup tersebut, subyek 1 mendapat protes dari keluarga khususnya cucu-cucunya yang selalu minta uang. Sedangkan pada kasus subyek 2 , setelah pensiun ia merasakan pemasukan gajinya berkurang, subyek 2 hanya menerima tiga perempat dari gajinya saja. Perubahan juga terjadi pada pola hidup keluarganya menjadi lebih hemat dan keluarga bisa menerimanya terutama anak-anak subyek 2 yang tidak banyak menuntut. Ia selalu menanamkan pada keluarganya apabila menginginkan sesuatu harus berusaha terlebih dahulu (Wawancara 6 September, 2013).

Bagi sejumlah individu, tidak bekerja lagi berarti hilangnya sumber keuangan. 
Hal ini mengakibatkan ber-ubahnya cara atau pola hidup individu dan keluarganya, yang sebelumnya hidup dengan berlebihan atau berkecukupan, kini harus lebih hemat. Individu juga harus mempersiapkan aktivitas atau usaha-usaha tertentu yang dapat menggantikan kekurangan yang dialami.

Pada subyek 1 setelah pensiun yang menjadi sumber perekonomian keluarga yaitu tambahan penghasilan suami dan dana pensiun. Setelah pensiun yang menjadi sumber perekonomian keluarga subyek 1 dan suaminya, diperoleh dari pemberian anak-anaknya yang sudah bekerja, serta subyek 1 yang memiliki simpanan tabungan pensiun. Strategi yang dapat dilakukan menghadapi masa persiapan pensiun yaitu dengan merencanakan dana pensiun yang dimiliki, sebagai kebutuhan mendasar yang menunjang kelangsungan hidup dimasa pensiun dan untuk mengantisipasi masalah besar yang akan terjadi dikemudian hari dalam hal ini berkurangnya pendapatan rutin.

Individu yang merupakan penopang hidup utama keluarga memiliki risiko terjadinya post power syndrome yang semakin besar. Faktor internal kemungkinan juga dapat menyebabkan post power syndrome. Subyek 1, ia cederung memiliki pribadi yang tertutup, apabila mengalami masalah subyek cenderung menyimpan masalahnya sendiri dari pada membicarakannya ke orang lain. Ia pun cenderung kurang memahami masalah yang dirasakan setelah pensiun. Beberapa kasus post power syndrome terjadi lebih parah bagi individu yang memiliki pribadipribadi yang dimana sakit yang disebabkan beban emosi tidak dapat tersalurkan. Sedangkan subyek 2, ia berusaha untuk menjalin komunikasi dengan semua keluarga besar dan anakanaknya, terkadang subyek bertukar pikiran dengan keluarga lain yang tinggal di depan rumah karena mereka sama-sama pensiunan PNS.
Jika dilihat dari aspek kesehatan, rekam medis kedua subyek dalam penelitian ini tidak mempunyai penyakit yang beresiko tinggi. Tetapi karena keterbatasan menggali informasi yang lebih dalam dari kedua subyek, hanya diperoleh informasi bahwa keduanya tidak pernah mempunyai rekam medis yang berat selama perjalanan karirnya menjadi guru. Menghadapi masa tua kini kondisi tubuh yang sering dialaminya yaitu munculnya kolesterol yang mudah menyerang pada kedua subyek penelitian.

\section{Upaya Pensiunan Guru Menghadapi Post-Power Syndrome}

Untuk mengatasi kejenuhan pasca kerja, para pensiunan melakukan beberapa kegiatan yang bermanfaat bagi dirinya sendiri maupun orang lain, diantaranya dalam bidang agama, sosial, ekonomi, dan pendidikan. Hal inilah yang bisa menjadi contoh untuk para pensiunan yang lain agar pasca kerja mempunyai sesuatu yang berharga untuk dirinya sendiri maupun untuk orang lain. Adapun setiap individu mempunyai kegiatan yang berbeda dengan individu yang lainnya, ini sama halnya dengan kedua subyek. Meskipun mereka mempunyai kesibukan yang sama dalam setiap bidang, tetapi waktu mereka tidak sama.

\section{Bidang Agama}

Upaya yang dilakukan dalam bidang keagamaan antara lain adalah sebagai berikut:

Dalam bidang keagamaan subyek 1 memanfaatkan waktu luang yang ada, seperti mengikuti kegiatan rutin pengajian yasinan yang dilaksanakan pada setiap malam jumat setelah shalat isya' sampai selesai, dalam acara tersebut ia turut serta menjdi pemateri. Pada kesempatan tersebut subyek 1 sering berbagi pengalaman yang pernah ia dapatkan. Selain kegiatan pengajian yasinan subyek 1 juga aktif mengikuti kultum setiap subuh di mesjid dekat rumahnya. Dalam rangka menambah khasanah ilmu agama ia juga 
sering mengikuti pengajian akbar yang di laksanakan di mesjid Agung Pacitan dari jam 19.00-selesai setiap dua minggu sekali (Wawancara 3 September, 2013).

Dalam bidang keagamaan subyek 2 memanfaatkan waktu luang yang ada yaitu seperti mengikuti kegiatan rutin pengajian yasinan yang dilaksanakan pada malam jumat sehabis shalat isya' sampai selesai. Disini ia menjadi ketua penggerak yasinan ibu-ibu. Disamping mengikuti kegiatan pengajian yasinan beliau juga mengikuti kegiatan lain dalam bidang keagamaan yaitu mengikuti kultum tiap ba'da subuh di masjid dekat rumah beliau (Wawancara 5 September, 2013).

\section{Bidang Sosial}

Selain bidang keagamaan kedua subyek juga mengisi waktu luangnya yang berhubungan dengan kegiatan sosial kemasyarakatan diantaranya yaitu:

Meskipun memasuki lansia akan tetapi subyek 1 aktif mengikuti kegiatan PKK dan menjadi anggota aktif. Ia menekuni kegiatan ini sudah dari dulu, sehingga subyek 1 faham betul dengan organisasi yang ada. Kegiatan ini dilaksanakan 1 bulan sekali yaitu setiap minggu ke 3. Disamping kegiatan PKK subyek 1 juga turut serta dalam kegiatan sosial lainnya seperti mengikuti sosialisasi lingkungan baik itu sosialisasi kesehatan, pendidikan, ataupun kewirausahaan. Hal ini ia lakukan supaya waktu yang ada sangat bermanfaat, kegiatan sosialisasi ini di laksanakan setiap 3 bulan sekali (Wawancara 3 September, 2013).

Sama dengan subyek 1 dalam bidang sosial kemasyarakatan, subyek 2 juga mengikuti kegiatan PKK yang di laksanakan setiap 1 bulan sekali. Akan tetapi ia mengikuti kegiatan ini hanya untuk mengisi waktu luangnya saja. Jadi subyek 2 tidak rutin setiap bulan datang. Selain PKK, ia juga sebagai tim penggerak kebersihan lingkunggan di sekitar rumahnya. Subyek 2 aktif disini karena mempunyai misi yaitu ingin menjalin kekompakan dengan warga sekitar lingkungannya dan juga melestarikan lingkungan supaya tetap bersih, indah, dan nyaman (Wawancara 5 September, 2013).

\section{Bidang Ekonomi}

Dalam bidang ekonomi subyek 1 memanfaatkan waktu yang ada dengan berbisnis kecil-kecilan untuk menambah penghasilan. Ia memiliki bisnis yang mudah dan mampu di jalani pada usianya yaitu dengan beternak ayam. Subyek 1 menekuni bidang ini semenjak beliau masih menjadi PNS, sehingga ternak ayam yang ia miliki sudah sangat banyak. Subyek 1 membagi tugas ini dengan partner terbaiknya yaitu suaminya. Hingga saat ini pun ia sangat menyukai kegiatan ini (Wawancara 3 September, 2013). Berbeda dengan subyek 1, subyek 2 juga membuka usaha kecil-kecilan dengan mendirikan kios sembako yang berada di depan rumahnya dan usaha ini ia tekuni bersama dengan suaminya hingga saat ini. Subyek 2 memiliki pemikiran bahwa usaha tersebut adalah usaha yang bagus, banyak diminati oleh konsumen dan merupakan kebutuhan sehari-hari. Subyek 2 berkeyakinan bahwa dengan mendirikan kios ia dapat mengisi waktu luang selain itu juga bisa untuk investasi masa depan (Wawancara 5 September, 2013).

\section{Bidang Pendidikan}

Dalam mengembangkan dibidang pendidikan subyek 1 turut serta mengajar TPA atau sebagai guru mengaji. Hal ini ia lakukan untuk menyalurkan ilmu yang subyek miliki dan tabungan amal untuk kehidupan akhirat kelak. Dengan mengajar ngaji ia merasakan seperti bekerja kembali seperti dulu, subyek 1 tidak merasa bosan dan sangat bahagia ketika bisa menyalurkan apa yang dia miliki, walaupun tidak mendapatkan gaji seperti yang dulu diterimanya ia tetap merasa bahagia. Subyek 1 mengajar TPA pada sore hari di masjid dekat rumahnya (Wawancara 3 September, 2013). Peran pensiun dapat diartikan dalam pengalihan 
peran, yaitu mengubah gaya hidup dengan menciptakan gaya hidup baru dan menyenangkn diri sendiri. Melepaskan berbagai peran lama dan menjalankan peran baru.

Menyalurkan kemampuannya dalam bidang pendidikan setelah purna tugas dengan mendirikan yayasan PAUD dan TK. Subyek 2 mengelola yayasan ini dengan dibantu oleh guru honorer. Dengan mendirikan yayasan tersebut banyak sekali manfaat yang dia dapat, tidak lain adalah tidak mematikan potensi yang ia miliki dengan menjadi guru dan di salurkan kembali di yayasan yang ia dirikan. Walaupun kurikulum dan metode berbeda namun menurutnya, ia mendapatkan pembelajaran yang lebih dari apa yang ia dapatkan dulu. Sampai sekarang subyek 2 masih aktif dalam yayasannya dan banyak sekali orang tua yang menitipkan anaknya di yayasan yang ia dirikan. Ini dikarenakan yayasan yang di kelola subyek 2 sangat baik sehingga orang tua yang menitipkan anaknya di yayasan tersebut sangat senang (Wawancara 5 September, 2013).

\section{Simpulan}

Berdasarkan pada hasil penelitian pada bahasan sebelumnya, dapat ditarik kesimpulan sebagai berikut:

Gejala post power syndrome yang ada dalam kajian penelitian ini dapat ditemukan bahwa emosi, fisik dan perilaku menjadi salah satu yang bisa dilihat dari subyek yang diteliti dalam kajian ini. Hasil yang di peroleh melalui proses wawancara dan observasi pada kedua subyek dalam penelitian ini dilihat dari cara subyek berkomunikasi dan informasi-informasi yang subyek sampaikan ketika proses pengambilan data.

Gejala yang dialami oleh subyek 1 terlihat ketika bercerita ia terlihat kurang fokus pada informasi yang ditanyakan, dari emosi ia mengalami sebuah gejala yang labil serta fisik sudah jelas terlihat dengan mengkerutnya kulit wajah dan tangan. Gejala dari perilaku tidak terlalu terlihat secara signifikan. Sedangkan, gejala yang dialami oleh subyek 2, dilihat dari segi emosi ia semakin labil, dilihat dair fisik gejala yang sangat terlihat adalah uban di rambut terlihat lebat, kulit semakin banyak keriput dan dilihat dari perilaku seperti orang yang sedang merasakan sesuatu yang dialami karena penyakit.

Faktor post power syndrome dari kedua subyek dalam penelitian ini dapat dilihat dari hilangnya jabatan subyek 1 yang dulu konsisten untuk mengajar tetapi setelah di usia yang cukup lanjut dipindah menjadi pengawas, dan subyek 2 pun merasa stress ketika pertama kali mengghadapi peralihan tugas tersebut. Faktor kehilangan rekan kerja, kewibawaan dan kehilangan sumber penghasilan. Tetapi dalam hal kehilangan sumber penghasilan tidak menjadi faktor utama dalam hasil yang didapat, karena kedua subyek bukan penopang hidup utama (kepala keluarga) dalam status keluarganya. Hal ini bukan faktor yang utama, sebab masing-masing subyek masih mempunyai suami. Kedua subyek penelitian ini masuk dalam kategori sikap pengalihan peran (Transformer), yaitu mengubah gaya hidup dengan menciptakan gaya hidup baru dan menyenangkan diri sendiri, melepaskan berbagai peran lama dan menjalankan peran baru.

Kesimpulan yang diperoleh dari kedua subyek bahwa tidak menutup kemungkinan dari kedua subyek tersebut kini telah memiliki aktivitas yang cukup untuk mengisi hari tua mereka tanpa harus ada beban yang berarti di antara kehidupan yang ada. Mereka tidak terlalu dipusingkan dengan kegiatan yang berhubungan dengan kehidupan dunia, misal tentang gaji dan lain-lain. Tetapi mereka syukuri hari tua dengan lebih lebih mendekatkan diri kepada sang kholiq dengan rajin salat berjama'ah dan rutin mengikuti pengajian mingguan di kampung halaman dan menjadikannya ibadah 
sebagai jalan spiritual mereka dalam mengisi hidup di dunia ini.

\section{Daftar Pustaka}

Abdurrahman, Dudung. (2002) Pengantar Metodologi Penelitian. Yogyakarta: IAIN Sunan Kalijaga Yogyakarta

Arikunto, Suharsimi. (2002) Prosedur Penelitian Suatu Pendekatan Praktek. Cetakan ke-5. Jakarta: PT. Reineke Cipta,

A.W. Widjaja. (2006) Administrasi. Jakarta: Rajawali Press

Clara, Agustina Maria. (2008) Pensiun, Stress dan Bahagia. http://www.allabout-stress.com (diakses tanggal 16 Juni 2013).

Djamarah S.B. (2005) Guru dan Anak Didik dalam Interaksi Edukatif, Suatu Pendekatan Teoritis Pedagogik. Jakarta: Rineka Cipta

Elia. (2003) Post Power Syndrome. http://www.sabda.org/publikasi/ekonsel079. (diakses tanggal 16 Juni 2013)

Fakhri, Syaiful. (2012) Dinamika Spiritual Pada Pensiunan. Skripsi tidak diterbitkan. Yogyakarta: Fakultas Ilmu Sosial dan Humaniora UIN Sunan Kalijaga

Flippo E.B. (1987) Manajemen Personalia, jilid ke-2. Alih bahasa oleh Moh. Masud. Jakarta: Erlangga

Hadayaningrat, Soewarno. (1999) Adminstrasi Pemerintahan dalam Pembangunan Nasional. Jakarta: Gunung Agung

Haditono. (1989) Mempersiapkan Diri Menghadapi Masa Pensiun. Yogyakarta: UGM Press

Hamalik, Oemar. (2004) Proses Belajar Mengajar. Jakarta: Bumi Aksara

Helmi, Avin Fadilla. (2000) Pengelolaan Stress Pra-Purna Bakti, Jurnal Psikologika 5(9)

\footnotetext{
Hurlock E.B. (1992) Psikologi Perkembangan. Terjemahan Istiwidayati dan Soedjarwo. Jakarta: Erlangga
}

Hurlock, Elizabeth B. (1996) Psikologi Perkembangan. Jakarta: Erlangga

Husnan, Ranupandojo H. (1987) Manajemen Personalia. Yogyakarta: BPFE

Idris, Y dkk. (2004) Buku pedoman upaya pembinaan kesehatan jiwa usia lanjut bagi petugas kesehatan. Jakarta: Departemen Kesehatan RI Direktorat Jenderal Bina Kesehatan Masyarakat

Idrus, M. (2007) Metode Penelitian Ilmuilmu Sosial: Pendekatan Kualitatif dan Kuantitatif. Yogyakarta: UII Press

Jacinta F.R. Pensiun dan pengaruhnya. http://www.e-psikologi.com.(diakses tanggal 15 Juni 2013).

Kamus Besar Indonesia. www.wikipedi.com.(diakses tanggal 14 Juni 2013)

Lexy J. Moleong.(2010) Metodologi Penelitian Kualitatif. Edisi revisi. Bandung: Rosda Karya

Lubis, Ilham Syuhada Aulya.(2011) Hubungan Harga Diri (self Esteem) Dengan Kecemasan Menghadapi Masa Pensiun Pada Anggota Kepolisian Daerah Sumatera Utara. Skripsi tidak diterbitkan. Yogyakarta: Fakultas Ilmu Sosial dan Humaniora UIN Sunan Kalijaga

Nasrun, M.W. Persiapan Mental untuk Pensiun. http://www.kompas.com. (diakses tanggal 15 Juni 2013)

Munandar. AS. (1991) Post Power Syndrome: Beberapa Pokok Pikiran Kelanggengan Usia Lanjut. Jakarta: Fakultas Kedokteran UI

Poerwadarminta. (1983) Kamus Umum BahasaIndonesia. Jakarta: Balai Putaka

Puji Purwanti. (2009) Post Power Syndrome Pada Purnawirawan Kepolisian Negara Republik Indonesia Ditinjau Dari Konsep Diri. Skripsi tidak diterbitkan. Semarang: Fakultas Psikologi UNIKA.http://eprints.unika.ac.id. (diakses tanggal 16 Juni 2013) 
Prawitasari JE. (1989) Mengelola Stress pada Masa Pensiun. Yogyakarta: Fakultas Psikologi UGM

Puspasari, Y. Hubungan antara Dukungan Sosial Teman dengan Tingkat Depresi pada Lanjut Usia di Panti Werdha Budhi Dharma Yogyakarta. eprints.undip.ac.id. (diakses tanggal 15 Juni 2013)

Rini JF. (2001) Pensiun dan Pengaruhnya. www.e-psikologi.com. (diakses tanggal 16 Juni 2013)

Santoso, Agus \& Lestari, Novia Budi. (2008) Peran Serta Keluarga pada
Lansia yang Mengalami Post Power Syndrome. Jurnal Media Ners, 2(1)

Sudarilah. (2012) Kiat-Kiat dalam Menghadapi Pensiun. Jurnal Wawasan STIE Kusuma Negara. 29(321) Juli-Agustus

Supeno. S. (1991) Realita Post Power Syndrome Pada Keluarga: Kelanggengan Usia Lanjut. Jakarta: Fakultas Kedokteran UI

Tanzeh Ahmad (2009) Pengantar Metode Penelitian.Yogyakarta: Teras.

Undang-Undang. (2005) Tentang Guru dan Dosen pasal 1 ayat 1 No. 14 
Psympathic, Jurnal Ilmiah Psikologi Juni 2016, Vol. 3, No. 1, Hal: 77 - 94 